\title{
СЛОВНИКОВА СТАТТЯ ЯК МЕТАМОВНИЙ КОГНІТИВНО-КОМУНІКАТИВНИЙ КОНСТРУКТ
}

У иентрі уваги статті перебувають проиеси метамовної реблексії як вияву особливої лінгвоментальної функції мови. Інтерпретаційну метамовну діяльність визначено як структурний компонент людської свідомості. Предметом дослідження є словниковий текст як безпосередній вияв метатінгвальної транспозииіі сутності мовного знака. У статті схарактеризовано основні науково-теоретичні положення сучасної науки, що стали підгрунтям для вивчення тексикографічного аспекту функціонування метамови. Словникову статтю кваліфіковано як лексикограбфічний (словниковий) метамовний конструкт, що в згорнутій метамовно-логічній формулі фіксує результати науково-емпіричного об'єктивно-суб'єктивного осягнення екзистенційних категорій автором-укладачем.

Ключові слова: метамова, словникова стаття, мовна діяльність, когнітивна діяльність.

Krekhno T., Demchenko N., Chala A. Dictionary Entry as a Metalinguistic Cognitive-communicative Construct. The article describes the processes of metalinguistic reflection as a manifestation of a special linguistic function of a language. Interpretive metalanguage activity is defined as a structural component of human consciousness.

The subject of the study is the vocabulary as a direct indication of the metalinguistic transposition of the essence of a linguistic sign. The article contains the main scientific and theoretical provisions of modern science, which have become the basis for studying the lexicographic aspect of the functioning of the metalanguage.

A dictionary entry is considered as a lexicographic (vocabulary) metalinguistic construct, which in the collapsed metalanguage logic formula captures the results of the scientific-empirical objective-subjective comprehension of existential categories by the author-compiler. Explication of the internal form of a linguistic sign is presented as a synthesis of cognitive, mental, linguistic processes of producer's consciousness. It focuses on the dialogicity and interactivity of the vocabulary text, its focus on optimizing the intellectual activity of the recipient on the decoding of the verbal-logical model and the further development of knowledge on its basis.

On the basis of the texts of the explanatory and encyclopaedic dictionaries the specifics of the vocabulary metatext are considered: zoning, the organization of obligatory and optional elements, the system of verbal and non-verbal signs, the way of representing the information, its amount, degree of deployment, the balance of informational, codification, pragmatic, intentional, evaluative functions. 
The conclusion is made about metalanguage as a universal code of comprehension and representation of information embodied in linguistic signs; about vocabulary text as a system construct, the content and structure of which are regulated by the conceptual foundations of a particular edition, lexicographic tradition and the subjective vision of the compiler; about the ambivalence of the dictionary entry, which is manifested in the strict regulation of the rules of lexicography and, at the same time, the freedom of interpretation in a certain range; the presence of explicit and implicit structures of metalinguistic transposition at information, codification, pragmatic, suggestive, axiological levels.

The prospects for the study of lexicographic text projected onto the linguodidactic plane and associated with the development of a methodology for the formation of knowledge about lexicographic text as a product of intellectual metalinguistic reflection are outlined.

Key words: metalanguage, dictionary entry, linguistic activity, cognitive activity.

\section{Вступ}

Заглиблення у внутрішню структуру мови, супроводжуване прикладними потребами іï функціювання, спонукало лінгвістів XX ст. до досліджень мови як формалізованої системи на підставі її знакового характеру. Діяльність структуралістів була скерована на максимальне наукове абстрагування лінгвістичних одиниць, подання їх у вигляді структурних схем - витворенні так званої мови другого порядку, або метамови.

Формалізоване подання мовних одиниць корелює $з$ філософською теорією логічного аналізу мови. Основоположник аналітичної філософії англійський мислитель Б. Рассел обстоював думку про те, що пізнання спирається не тільки на логічний аналіз, а й на мовні знаки як логічні засоби категоризації знання. Так філософ визнавав необхідність вироблення апріорної метамови, що узгоджуватиметься з математичною логікою і становитиме засіб пізнання світу та пошуку істинного знання (Рассел, 2000).

Рецепції поняття мова другого порядку лінгвістичною площиною засвідчують наукову зацікавленість в осмисленні специфічної мовної функції. Французький мовознавець А. Мартіне окреслив поняття метамови як лінгвістичну структуру, що постає в спеціальній функції: $є$ засобом опису природної людської мови; іншими словами - це мова для опису мови (Мартине, 1960: 453). 
Представник класичної лінгвістичної науки американець Р. Якобсон уперше виокремив метамовну функцію вербальної комунікації, що полягає насамперед у додатковому уточненні, тлумаченні певної одиниці мовлення, незрозумілої адресатом у ході спілкування. Метамовна діяльність фіксується ще в ранньому дитинстві, оскільки розвиток дитини тісно пов'язаний зі здатністю й потребою трактувати почуті мовні одиниці, зіставляти з іншими знаками з метою їх тлумачення. Так дитина «виробляє в собі метамову», говорить із собою мовою про мову (Якобсон, 1985: 316). Метамовна функція залишається актуалізованою впродовж життя, адже в мовній практиці триває процес осягнення нових аспектів мови, постійно здійснюється комунікативний контроль за розумінням висловлень. У процесі метамовних операцій постають пропозиційні рівняння: А = Б, тобто мовна одиниця дорівнює іншим знакам цієї мови. Засобами метамовної інтерпретації лінгвіст називає перифрази, синонімічні одиниці, переклади іншою мовою, перекодування в знаки-символи немовної природи (Якобсон, 1985: 236, 294). Р. Якобсон визнає унікальність властивості мовної системи встановлювати відношення еквівалентності, адже транспозиція мовного факту одночасно збагачує думку, забарвлює іiї новими відтінками смислу, сама постає засобом пізнання поняття, названого певним словом: «Увесь наш досвід перебуває в комплементарних відношеннях з метамовними операціями; когнітивний рівень мови не тільки допускає, але й вимагає інтерпретаційного перекодування» (Якобсон, 1985: 316-317, 366).

До осмислення феномену метамови в класичній лінгвістиці залучають теорії М. Бахтіна. Міркування науковця щодо металінгвістичної природи мови грунтуються на положенні про діалогічність тексту. Згідно з ученим, навіть формально нейтральний та об'єктивний письмовий текст наукового стилю позначений, з одного боку, досвідом, рівнем наукової обізнаності, інтуїцією автора, а з другого, - певними замірами щодо передбачуваного адресата. Оскільки не існує абсолютно нового знання, а кожне висловлення базується на вже відомих фактах, то науковий текст явно чи імпліцитно міститиме авторське ставлення до об’єкта опису, його акцептуацію або неприйняття, позитивну оцінку або критику (Бахтин, 2000: 288). Так само адресат вступає в діалог з письмовим текстом шляхом його інтерпретації, укладання пропозиційних рівнянь, перекладу актуальними для себе 
мовними знаками. Комбінація концептів - трансльованих автором й інтерпретованих у свідомості адресата метамовними засобами становить результат діалогічної комунікації наукового тексту й реципієнта (Бахтин, 2000: 295-296).

Таким чином, у процесі наукових абстрагувань представники різних мовознавчих напрямів виокремили особливу лінгвоментальну функцію - метамовну. Завдяки цій функції уявлення про позамовні реалії, що були втілені насамперед у знаках природної мови, набувають можливості інтерпретуватися та транспозиціонуватися метамовними знаками. Метамовний конструкт формують психічні й когнітивні процеси адресанта та адресата за участю мовних знаків.

Однією з площин реалізації метамовної функції постають лексикографічні тексти. Словникова стаття становить безпосередній вияв металінгвальної транспозиції мовного знака: ліва реєстрова частина репрезентує одиниці різних рівнів, а права врівноважує їх сутність шляхом експлікації іншими знаками природної мови.

Підгрунтя для розбудови науково-теоретичних та прикладних положень лексикографічного аспекту функціювання метамови було закладено у працях сучасних лінгвістів - Н. Гвішіані, О. Демської, П. Денисова, Є. Карпіловської, С. Карцевського, І. Куликової, Д. Салміної та інших. Ці вчені зосереджувалися на таких питаннях: механізми метамовного подання знань про світ у словниках, компоненти словникового тексту, способи семантизації реєстрового слова, співвідношення об’єктивних знань і суб’єктивної авторської позиції у словниковій статті, прагматичний аспект метатексту, його діалогічність, трансформація словникового тексту на тлі динамічних змін у колективній та індивідуальній свідомості. Однак наукові шукання в окресленій галузі не є вичерпними насамперед через багатовимірність і складність природи лексикографічного тексту, що синтезує процеси когнітивної, психічної та мовної діяльності суб’єктів метамовної взаємодії - автора та реципієнта. Актуальність вивчення різних аспектів словникової статті зумовлена також безупинністю процесів розбудови металінгвального рівня мови відповідно до еволюції наукової думки, трансформації форм і засобів наукового пізнання.

Мета роботи - схарактеризувати усталені в наукових колах погляди на лексикографічний текст як особливу форму кодифікації 
знання; на матеріалі окремих словникових статей виявити засоби й способи метамовно-логічної репрезентації результатів осмислення категорій буття автором-укладачем; дослідити компоненти мікроструктури тексту, зорієнтовані на взаємодію з реципієнтом.

\section{Методи дослідження}

Застосовані підходи та методи спрямовані на осягнення багатопланової природи лексикографічного тексту. Серед них - теоретичні й емпіричні. Теоретичні методи передбачають вивчення наукової літератури з проблеми дослідження, узагальнення теоретичної інформації, систематизацію наукових здобутків і накреслення перспектив.

3 емпіричних методів релевантними для дослідження $є$ такі: метод лінгвістичного опису (аналітичні процедури в рамках цього методу спрямовані на виявлення структурних елементів об'єкта вивчення, їх атрибутивних ознак, специфіки комбінування); структурний метод (реалізується в ході компонентного аналізу смислової структури слів); інтерпретаиійний метод (застосовується в контексті теоретичної установки на розуміння знакового, семіотичного характеру одиниць мови); функціональний метод (слугує глибшому осягненню прагматичного дискурсу об’єкта дослідження).

Названі методи застосовуються на тлі антропоцентричного підходу: людина $є$ основним мірилом вивчення лексикографічного тексту, адже всі параметри словникової статті опосередковані психічними процесами людської свідомості.

\section{Виклад основного матеріалу}

Теоретик лексикографічної науки П. Денисов кваліфікує словникову статтю як складний предикат метамовлення, причому зазначає, що семіотичні елементи тексту генерують наукове знання в тісній взаємодії з лінгвістичними, соціолінгвістичними й психолінгвістичними параметрами, одночасно закладеними в метамовні знаки (Денисов, 1977).

Цю тезу П. Денисова розгортає російський мовознавець Н. Гвішіані: «Метамова (...) не може бути відірваною від індивіда - людини, котра, реалізуючи метамову, породжує метамовлення. Тому метамова через посередництво метамовлення виявляється не тільки національно й соціально зумовленою, а й залежною від ідей, поглядів, загальної методологічної позиції учених, що нею послуговуються» (Гвишиани, 1983: 67). 
Мовознавці І. Куликова і Д. Салміна трактують лексикографічний метамовний опис слова як специфічний тип знакової кодифікації наукового знання про одиниці мови. Причому ця кодифікація має інтелектуально-комунікативний характер, оскільки в предикатній частині міститься не тільки дефініція, а й одночасно стимули до пізнання, імпульси до формування поняття у свідомості реципієнта, установки на систематизацію знання. Ця інформація втілюється як у лексемах (термінах і загальновживаних мовних одиницях у спеціальній функції), так і у своєрідному синтаксисі та системі граматичних зв’язків між компонентами (Куликова, \& Салмина, 2002: 98-101).

У дослідженнях лексикографічного тексту М. Жуйкова зосереджується на його когнітивній природі. Мисленнєво-пізнавальний компонент словникової статті найбільшою мірою виявляється в метамовних дефініціях, де зафіксовані результати людського досвіду, пізнання, мислення. Експлікацію лексичного значення мовознавець подає як синтез універсальних когнітивних процедур та індивідуальних. Універсальні психічні процеси скеровують думку людини в напрямку ідентифікації, розрізнення гіпоніма й гіпероніма, аналізу, категоризації. Інформація ж, що надходить індивідуальними перцептивними каналами (візуальними, сенсорними, трансцендентними), фіксується в диференційних семах і має специфічне національне, культурне або суто індивідуально-світоглядне забарвлення. Через це фактично неможливе конструювання абсолютно ідентичних дефініцій різними суб'єктами-лексикографами. М. Жуйкова зазначає, що уніфікації може не бути навіть у найбільш об’єктивній опорній частині дефініції, де предмет опису зіставляється з певною родовою категорією: дуб 'листяне дерево' - категорія наївної картини світу; дуб 'дерево сімейства букових' - результат наукового абстрагування. Диференційні семи тим більше постають маніфестантами різних індивідуальних концептосфер, де центральні й периферійні елементи можуть не збігатися. Звісно, антропоцентризм лексикографічного продукту виявляється в одночасній проєкції цієї авторської концептосфери на передбачувані індивідуальні концептосфери цільової аудиторії (Жуйкова, 2016).

Як засвідчує мовознавець 3. Козирєва, психолінгвістична й соціолінгвістична природа новітнього словникового метатексту виявляється серед іншого в порушенні принципу науковості. Цей факт 
зумовлений суперечністю між тяглістю процесу оновлення лексичного фонду й моментальною синхронною фіксацією ще не стабілізованих норм у словниках, що є реакцією на нагальні комунікативні потреби суспільства (Козирєва, 2015).

Досліджуючи способи репрезентації внутрішньої форми ідеологічно маркованих мовних знаків у словниках різних історичних періодів, Є. Карпіловська висновує: зрушення у стереотипній колективній свідомості отримують відбиток на всіх рівнях словникового тексту (Карпіловська, 2012).

Насамперед ліва частина словника віддзеркалює прагнення лексикографів змоделювати концептуальну сітку свідомості потенційних користувачів. Залучаючи до реєстру ідеологічно значущі для свого часу мовні одиниці, укладачі задають діапазон думки читачів, спонукають їх до оперування пропонованими поняттями, до опосередкування власної когнітивної діяльності визначеними стереотипними мовними знаками (соизмагання, неповерненець, передовик, стахановец, ).

Словотвірний рівень лексикографічної метамови також засвідчує трансформацію суспільного уявлення про предмет, позначуваний певним мовним знаком. Понятійне поле „особа, яка провадить бізнес” в академічному словнику української мови (1970) подане так: бізнесмен; у словнику-довіднику «Нове в українській лексиці» (2002) - бізнесмен, бізнесовещь. Ухвалу автора залучити до реєстру словотвірне надбання нової доби - бізнесовець - Є. Карпіловська кваліфікує як свідчення деідеологізації стереотипу, адже для вираження поняття апробується продуктивна модель української деривації. Англіцизм сприяв дистанціюванню суспільства від непривабливої реалії; нейтралізація негативу в суспільній свідомості зумовила активізацію словотвору, відтак віддзеркалення цього процесу в словнику (Карпіловська, 2012: 90-91).

Розгляньмо специфіку словникового метатексту на матеріалі лексичних одиниць одного понятійного поля - „педагогіка”. Матеріалом аналізу слугуватимуть тексти енциклопедії «Український педагогічний словник» (1997) укладача С. Гончаренка та тлумачного словника «Новий тлумачний словник української мови» (2001) лексикографів В. Яременка, О. Сліпушко. 
Крехно Т. І., Демченко Н. Д., Чала А. Г. Словникова стаття як метамовний когнітивно-комунікативний конструкт

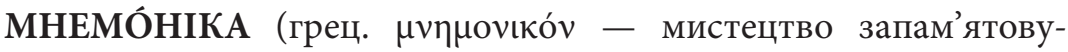
вання) - система засобів, які полегшують запам'ятовування й збільшують обсяг пам'яті. В основі лежить процес створення нових асоціацій між об’єктами, що важко запам’ятовуються. Мнемонічні зв’язки підкріплюють запам'ятання матеріалу, але не компенсують його (Гончаренко, 1997: 212).

Еквівалентність реєстрової одиниці й предикатного метатексту встановлюється за допомогою чотирьох зон: 1) етимологія; 2) категоризація; 3) деталізація істотних ознак поняття; 4) зона прагматики. Така структура метатексту енциклопедичного словника не $є$ обов'язковою; вона, швидше, продиктована суб'єктивним авторським розумінням оптимальної структури й кількості матеріалу для збалансування обох частин пропозиційного рівняння. Зона етимології $€$ факультативною в довідникових виданнях енциклопедичного типу; навіть у межах описуваного педагогічного словника не всі реєстрові слова супроводжуються відомостями про походження. Очевидно, що подана етимологічна довідка слугує вмотивуванню незрозумілої зовнішньої форми іншомовного знака; завдяки семантико-історичній інформації абстрактна для читача лексична одиниця набуває більш осмисленої внутрішньої форми. Отже, наявність зони етимології зумовлена прагненням автора оптимізувати процес входження терміна в мовну свідомість реципієнта.

У зоні категоризації предмет, позначуваний реєстровим словом, співвідноситься з певним загальним родовим поняттям (система засобів), потім ототожнюється з видовими класами (що полегшують запам'ятовування; щз збільщують обсяг пам’яті). Так наукове знання втілюється у вербальній логічній формулі віднесення об'єктів до певних множин і підмножин. Чіткій об’єктивації багатокомпонентної думки підпорядкований і синтаксис: родо-видова ієрархія знайшла відображення в залежності головної і підрядної частин складного речення. Додаткова сутнісна характеристика поняття, що допомагає його ідентифікувати серед інших видових об'єктів (зона деталізаціі), так само втілена у складнопідрядному реченні.

Лексичний рівень транспозиціонованого наукового знання про мнемоніку репрезентовано стилістично маркованими одиницями: терміни (мнемонічници); абстрактна лексика (запам'ятовування, процес, асоиіація, об’єкт,обсяг), зокрема одиниці, що допомагають 
систематизувати предмети, схарактеризувати їхні залежності (системa, зв'язки). Добір і комбінація цих лексичних одиниць регламентовані стандартами наукового тексту. Водночас до інтерпретації сутності реєстрового слова автор залучає лексеми, що містять оцінний компонент: полегшують (запам'ятовування), збільшують (обсяг пам'яті). Емоційна кваліфікація предмета опису має вплив на волю й почуття людини. Лексикограф, конструюючи вербально-логічну репрезентацію поняття, а) інтенсифікує аспект позитивної конотації; б) скеровує когнітивні процеси адресата в напрямку осягнення поняття як доцільного, ефективного, оптимального засобу вирішення певних життєвих чи виробничих завдань. Отож, зашифровані на рівні лексики інтенції автора мають кодифікаційний, інформаційний, сугестивний, а також прагматичний характер.

Найбільш виразно прагматика метатексту виявляється в четвертій зоні: Мнемонічні зв'язки підкріплюють запам'ятання матеріалу, але не компенсують його. Це твердження є нібито відповіддю комуніканта на передбачувані умовиводи аудиторії педагогічного словника щодо абсолютизації мнемоніки як методичного засобу. Метатекстове розгортання думки автора спрямоване на дискурсну площину безумовність й самодостатність мнемоніки: словникар імпліцитно протиставляє засоби, що базуються на раціональній діяльності та логічних міркуваннях. Формально ця думка виражена в кон'юнкції двох логічних істинних суджень, що в комунікативному плані висловлюють модифіковане застереження (за допомогою сполучника але).

ГЕНІА́ЛЬНІСТЬ (від лат. genialis - властивий генієві, плідний) - найвищий ступінь о 6 д а р о в а н о с т і, прояву творчих сил людини. Термін “геніальність” вживають як для позначення здатності людини до творчості, так і для оцінки її результатів. І. Кант, Г. Лейбніц, Г. Лессінг, Д. Дідро вважали головною рисою Г. інтуїтивні здібності (див. Інтуїція). Відміна Г. від т а л а н т у в ступені обдарованості і, головне, в суспільній значущості творчості: геній створює нову епоху у своїй галузі (Гончаренко, 1997: 21).

Поняття геніальність у теорії загальної педагогіки розглядають у контексті суміжних явищ - задатки, здібності, обдарованість, талант. Розв'язання педагогічних завдань передбачає попереднє розмежування цих феноменів та осягнення їх сутності. 
Крехно Т. І., Демченко Н. Д., Чала А. Г. Словникова стаття як метамовний когнітивно-комунікативний конструкт

У зоні етимології закладається основа для формування поняття шляхом подання графічного образу одиниці та ії семантики в мовіджерелі.

Змістове наповнення тлумачної частини містить такі компоненти:

1) категоризація поняття; 2) характеристика ужиткового узусу; 3) авторизація сутнісної ознаки; 4) відмежування від дотичного поняття; 5) оцінка суспільного значення.

Особливістю кількаразової транспозиції знання про геніальність у різних зонах метатексту є те, що центральними одиницями метамовних суджень виступають інші терміни того самого понятійного поля: обдарованість, здібність, інтуїия, талант, що також потребують дешифрування, оскільки становлять собою концентрацію наукових смислів. На винятковість значення цих базових понять для витлумачення заголовкового слова вказують застосовані автором невербальні метазасоби: розрядка шрифту (об дар о в а н і с т ь ; т а л а н т), курсив (Інтуїція); а також метамовна позначка див., що має функцію перехресного посилання. Лексикографічне осмислення поняття таким чином прямує не звичним шляхом з'ясувального тлумачення, а шляхом формування семантичної мережі, вузлами якої $€$ ключові поняття-терміни. Взаємовідношення між вузлами накреслені у спосіб суміжності (геніальність - обдарованість), включення (геніальність - інтуӥція), протиставлення (геніальність - талант). Когнітивно-семантичну мережу доповнюють персоналії - I. Кант, Г. Лейбніц, Г. Лессінг, Д. Дідро. Сконструйований у такий спосіб метатекст $є$ продуктом мисленнєво-когнітивних метамовних операцій автора в процесі рефлексій над поняттям й одночасно активатором інтелектуальної інтерпретації у свідомості читача-адресата. Задана динаміка тексту буде реалізовуватися в подальшому зважуванні співвідношень окреслених множин (геніальність, обдарованість, здібність, інтуїиія, талант, а також I. Кант, Г. Лейбніи, Г. Лессінь, Д. Дідро), у з'ясуванні зон їхньої дотичності, перетину чи накладання. Очевидно, що виявлені понятійно-смислові значення досліджуваних категорій та особливості їх взаємодії в одній парадигмі здебільшого будуть позначені пріоритетністю окремих понять в уявленні реципієнта, індивідуальними характеристиками мовної особистості та конкретними комунікативно-пізнавальними завданнями. 
Одним із центральних понять тематичної групи «педагогіка» $є$ одиниця вчитель.

УЧИТЕЛЬ (ВЧИТЕЛЬ), Я, ч. 1. Особа, яка навчає, викладає який-небудь навчальний предмет у школі; педагог, викладач, викладовець, навчитель. 2. Людина, яка $є$ авторитетом у якій-небудь галузі, яка впливає на інших, передає свій досвід, знання, служить для них прикладом (Яременко, \& Сліпушко, 2001: 640).

Інтерпретація мовного знака зумовлена типологією праці тлумачний словник загальний типу, - а отже, передбачає репрезентацію насамперед семантичних, граматичних, фонетичних, орфоепічних параметрів слова як одиниці мовної системи. Ці відомості об'єктивуються за допомогою традиційних метамовних засобів: знак наголосу; фонетичний варіант у дужках; флексія відмінкової форми, котра, вірогідно, може становити граматичну трудність; графічне скорочення назви граматичної категорії; стислий словесний опис семантичної структури - мінімальна водночас достатня інформація, утілена в усталеній логічній формулі віднесення денотата до роду з подальшим з'ясуванням видових диференційних ознак; розмежування цифрами 1, 2 значень полісемантичного слова в одній словниковій статті.

Специфікутлумачноїчастини становить поєднання з'ясувального та синонімічного типів тлумачення прямого номінативного значення слова учитель:

1. Особа, яка навчає, викладає який-небудь навчальний предмет у школі; педагог, викладач, викладовець, навчитель. Така конверсія заголовкового слова формує метатекст із потужними потенціями інтерактивної взаємодії, діалогічності, розгортання процесу пізнання реєстрового слова не тільки як мовної одиниці, а також як поняття. Власне, це текстова метакомунікативна ситуація. Текст, що розгортався і сприймався читачем лінійно, у частині синонімічного тлумачення оформлюється як інформаційна надбудова, розкодування якої скеровується в різних напрямках. По-перше, у напрямку осягнення парадигматичних відношень лексеми в тісному зв'язку з прагматичним аспектом: з'ясування семантичних нюансів, стилістичної маркованості, рівня експресивності одиниць синонімічного ряду підпорядковане, зрештою, ефективному рішенню комунікативних завдань. По-друге, у напрямку глибшого осягнення сигніфікативного 
значення заголовкового слова. Адже із семантичного обсягу синонімів педагог, викладач, викладовець, навчитель можуть бути вилучені й по-новому скомбіновані масиви інформації щодо мотивованості, глибинних і поверхневих структур значення, емоційно-оцінної кваліфікації, етнічно-культурної специфіки тощо. Подані слова стимулюють формування нових мереж асоціацій і конотацій, активують пласти як загальносуспільної концептуальної інформації, так і індивідуальної. Відповідно, нові знання можуть вплинути на модифікацію поданого насамперед з'ясувального тлумачення.

Окрім того, наявність синонімічного типу пояснення значення засвідчує скерованість свідомості автора в напрямку формування мовної особистості, визначальними рисами якої є критичність мислення й усвідомлення персональної відповідальності за розбудову мови. Адже поданий ряд синонімів репрезентований як нормативними загальновживаними одиницями - педагог, викладач, так і лексемами, обмеженими у вживанні й некодифікованими - навчитель, викладовець. Таке подання матеріалу об'єктивно відбиває процеси сучасного моделювання української мови, сповнені сміливих експериментів на рівні запозичень і словотвору; скеровуваних як еволюційними законами, так і суб'єктивними уподобаннями (Клименко, Карпіловська, \& Даниленко, 2003; Караванський, 2001). Автор не здійснює маркування синонімів ремарками заст., рідко, зах. і подібними, чим спонукає інтерпретаторів тексту до самостійного дослідження статусу лексем, оцінки доцільності їх залучення до мовотворчих процесів сучасності. Ухвалюючи рішення щодо включення чи невключення до власного мовлення цих слів, користувач словника одночасно бере на себе місію унормування лексичного рівня, прогнозування чи освоєння намічених тенденцій розвитку мови.

\section{Висновки}

Отже, словникова стаття є прямою формою реалізації металінгвальної функції мови. Ця функція актуалізована об’єктивною, колективно усвідомленою потребою опису, тлумачення, систематизації й кодифікації мовних явищ як відображення наукових, емпіричних та наївних знань про світ. Реалізація метамовних рефлексій у лексикографічних текстах одночасно опосередкована такими мовними функціями, як комунікативна, інформативна, номінативна, когнітивна, 
мислетворча, волюнтативна, експресивна, емотивна, прагматична, акумулятивна. Така багатоплановість зумовлена взаємозалежністю метамовних операцій і психічної активності людської свідомості. Специфічну діяльність логічних, когнітивних та емоційно-образних структур мислення, спрямовану на інтерпретацію понятійних і ціннісних смислів мовних знаків та їх повторне згортання в логічновербальні формули, науковці кваліфікують як процеси метамовної свідомості.

Значущість метамовних лексикографічних текстів полягає в тому, що вони в концентрованому узагальненому вигляді репрезентують позначувані мовними одиницями багатовимірні фрагменти дійсності; шляхом компресії збалансовують інформацію про мовний знак і його предметну, понятійну, конотаційну, аксіологічну, суспільно-історичну детермінованість. Таким чином словникові статті постають оптимальними, зручними для оперування одиницями в ході розбудови наукового знання.

Концентрація суджень досягається завдяки застосуванню особливої знакової системи - вербальних і невербальних метамовних засобів. До вербальних зараховують одиниці лексичного, граматичного, синтаксичного рівнів мови, ремарки, посилання, графічні скорочення; до невербальних - умовні графічні позначки, шрифтові модифікації. В умовах реалізації завдань з організації інформаційних масивів загальновживані лексеми постають одиницями понятійнологічного мислення, атрибутивними ознаками яких є чіткість, нейтральність, об’єктивність, адекватність, висока інформативність.

Метатекст може розгортатися лінійно (завдяки звичній формально-синтаксичній організації речень зокрема та тексту в цілому), водночас може мати багатопланові надбудови, що формуються за допомогою системи ремарок, посилань, нелінійних типів з'ясування значення. Різні компоненти метатексту можуть більшою чи меншою мірою реалізовувати окремі функції: інформаційну, кодифікаційну, прагматичну, інтенціональну, мотиваційну, оцінну тощо. Причому їх вияв може бути як експліцитним, так і імпліцитним.

Подана у словниковій статті редукована модель знання, претендуючи на об’єктивність, водночас не може не відображати авторської позиції, досвіду, мотивів, задумів. Активна інтелектуальна діяльність із виявлення концептуальних структур описуваної одиниці, 
їх інтерпретації та подальшого згортання в лексикографічний метамовний конструкт маніфестує мовну особистість автора-укладача. Сконструйоване в такий спосіб нове знання стимулює комунікацію з уявним адресатом, урухомлює когнітивно-інтелектуальні механізми свідомості читацької аудиторії словника.

У контексті вищесказаного виразно об'єктивується серед інших проблема лінгводидактичної площини, пов’язана 3 методологією формування знань про лексикографічний текст як продукт специфічної інтелектуальної метамовної рефлексії. Адже ефективна взаємодія авторського тексту й реципієнта можлива лише за умови, якщо всі учасники комунікації володіють однаковим кодом фіксації і, відповідно, зчитування концептуальних смислів, зашифрованих у структурі словникової статті. Обізнаність із цим кодом відкриває широкі можливості розбудови індивідуумом концептуальної картини світу відповідно до своїх запитів.

\section{ЛІТЕРАТУРА}

1. Бахтин, М. М. (2000). Автор и герой: к философским основам гуманитарных наук. Москва: Азбука. 2. Гвишиани, Н. Б. (1983). К вопросу о метаязыке языкознания. Вопросы языккознания, 2, 64-72. 3. Гончаренко, С. У. (1997). Український педагогічний словник. Київ: Либідь. 4. Денисов, П. Н. (1977). Типология учебных словарей. В Проблемы учебной лексикографии (с. 23-42). Москва: Изд-во МГУ. 5. Жуйкова, М. (2016). Словникові дефініції та принцип антропоцентризму. Актуальні питання іноземної філологіï, 4, 61-68. 6. Караванський, С. (2001). Пошук українського слова, або боротьба за національне «Я». Київ: Академія. 7. Карпіловська, Є. А. (2012). Реакція мови на зміну суспільних стереотипів. Наукові записки НаУКМА. Філологічні науки, 137, 88-91. 8. Клименко, Н. Ф., Карпіловська, Є. А., \& Даниленко, Л. І. (2003). Динаміка словникового складу сучасної української мови на тлі міжслов'янських паралелей. Мовознавство, 2-3, 96-111. 9. Козирєва, 3. Г. (2015). До питання лексикографічної інтерпретації динаміки сучасного українського лексикону. Науковий вісник кафедри Юнеско КНЛУ. Серія «Філологія. Педагогіка. Психологія», 31, 77-85. 10. Куликова, И. С., \& Салмина Д. В. (2002). Введение в металингвистику (системный, лексикографический и коммуникативно-прагматический аспекты тингвистической терминологии). Санкт- Петербург: САГА. 11. Мартине, А. (1960). О книге «Основы лингвистической теории» Луи Ельмслева. Новое в зарубежной лингвистике, 1, 437462. 12. Рассел, Б. (2000). Человеческое познание: его сфера и границы. Москва: ТЕРPА - Книжный клуб: Республика. 13. Якобсон, Р. (1985). Избранные работыл. Москва: Прогресс. 14. Яременко, В. В., \& Сліпушко, О. М. (2001). Новий тлумачний словник української мови (2-е вид., випр.). (Т. 3: П-Я). Київ: Аконіт. 


\section{REFERENCES}

1. Baxtin, M. M. (2000). Avtor i geroj: $k$ filosofskim osnovam gumanitarnyx nauk [Author and hero. To the philosophical found ations of the humanitarian sciences]. Moskva: Azbuka [in Russian]. 2. Gvishiani, N. B. (1983). K voprosu o metayazyke yazykoznaniya [To the question of the metalanguage of linguistics]. Voprosy yazykoznaniya - Questions of linguistics, 2, 64-72 [in Russian]. 3. Honcharenko, S. U. (1997). Ukrainskyi pedahohichnyi slovnyk [Ukrainian pedagogical dictionary]. Kyiv: Lybid [in Ukrainian]. 4. Denisov, P. N. (1977). Tipologiya uchebnyx slovarej [Typology of educational dictionaries]. In Problemy uchebnoj leksikografii - Problems of educational lexicography (pp. 23-42). Moskow: Izd-vo MGU [in Russian]. 5. Zhujkova, M. (2016). Slovnykovi definiciji ta pryncyp antropocentryzmu [Dictionary definitions and the principle of anthropocentrism]. Aktualni pytannia inozemnoji filolohiji -Topicalis sues foreign philology, 4, 61-68 [in Ukrainian]. 6. Karavanskyi, S. (2001) Poshuk ukrajinskoho slova, abo borotba za natsionalne "ja» [The search for the Ukrainian word, or the struggle for the national self]. Kyiv: Akademija [in Ukrainian]. 7. Karpilovska, Je. A. (2012). Reakcija movy na zminu suspilnych stereotypiv [The reaction of language to change social stereotypes]. Naukovi zapysky NaUKMA. Filolohichni nauky - Scientific notes of National University of "Kyiv-Mohyla Academy». Philological Science, 137, 88-91 [in Ukrainian]. 8. Klymenko, N. F., Karpilovska, Je. A., \& Danilenko, L. I.(2003). Dynamika slovnykovoho skladu suchasnoji ukrajinskoji movy na tli mizhslovjanskych paralelej [Dynamics of the vocabulary of contemporary Ukrainian language against the background of inter-Slavic parallels]. Movoznavstvo - Linguistics, 2-3, 96-111 [in Ukrainian]. 9. Kozyrieva, Z. H. (2015). Do pytannia leksykohrafichnoji interpretacij i dynamiky suchasnogo ukrajinskoho leksykonu [On the lexicographic interpretation of the dynamics of modern Ukrainian vocabulary]. Naukovyi visnyk kafedry JUNESCO KNLU. Serija Filolohija. Pedahohika. Psycholohija - Scientific news letter of the UNESCOD epartment of Kyiv National Linguistic University. Philology Series. Pedagogy. Psychology, 31, 77-85 [in Ukrainian]. 10. Kulikova, I. S., \& Salmina, D. V. (2002). Vvedenie $v$ metalingvistiku (sistemnyj, leksikograficheskij i kommunikativno-pragmaticheskij aspekty lingvisticheskoj terminologii) [Introduction to metalinguistics (system, lexicographical, and communicative- pragmatic aspects of linguistic terminology)]. Sankt-Peterburg: SAGA [in Russian]. 11. Martine, A. (1960). O knige «Osnovy lingvisticheskoj teorii» Lui El'msleva [About the book «Fundamentals of linguistic theory» by Louis Elmslev]. Novoe v zarubezhnoj lingvistike - New in foreign linguistics, 1, 437-462 [in Russian]. 12. Rassel, B. (2000). Chelovecheskoe poznanie: ego sfera i granicy [Human knowledge: its scope and boundaries]. Moskva: TERRA - Knizhnyj klub: Respublika [in Russian]. 13. Yakobson, R. (1985). Izbrannye raboty [Selected Works]. Moskva: Progress [in Russian]. 14. Jaremenko, V. V., \& Slipushko, O. M. (2001). Novyi tlumachnyi slovnyk ukrajinskoji movy [New Explanatory Dictionary of the Ukrainian Language]. (Vol. 3). Kyiv: Akonit [in Ukrainian].

Крехно Тетяна Іванівна - кандидат філологічних наук, доцент, професор кафедри української лінгвістики, літератури та методики навчання, Комунальний заклад «Харківська гуманітарно-педагогічна академія» Харківської обласної ради; пров. Руставелі, 7, Харків, 61001, Україна.

Tel. +380677847681

E-mail: krekhno.t@i.ua

https://orcid.org/0000-0002-6656-4808 
Krekhno Tetiana Ivanivna - Ph.D. in Philology, Docent, Professor at the Department of Ukrainian Linguistics, Literature and Teaching Methods, Municipal Establishment «Kharkiv Humanitarian-Pedagogical Academy» of Kharkiv Regional Council; Rustaveli Ln., 7, Kharkiv, 61001, Ukraine.

Демченко Наталя Дмитрівна - кандидат філологічних наук, доцент, завідувач кафедри української лінгвістики, літератури та методики навчання, Комунальний заклад «Харківська гуманітарно-педагогічна академія» Харківської обласної ради; пров. Руставелі, 7, Харків, 61001, Україна.

Tel. +380506410807

E-mail: demchenko_natalia@ukr.net

https://orcid.org/0000-0002-5792-0428

Demchenko Natalia Dmytrivna - Ph.D. in Philology, Docent, Head of the Department of Ukrainian Linguistics, Literature and Teaching Methods, Municipal Establishment «Kharkiv Humanitarian-Pedagogical Academy» of Kharkiv Regional Council; Rustaveli Ln., 7, Kharkiv, 61001, Ukraine.

Чала Анна Геннадіївна - кандидат педагогічних наук, доцент кафедри української лінгвістики, літератури та методики навчання, Комунальний заклад «Харківська гуманітарно-педагогічна академія» Харківської обласної ради; пров. Руставелі, 7, Харків, 61001, Україна.

Tel. +380989379559

E-mail: anya.chalaya@ukr.net

https://orcid.org/0000-0002-5915-0965

Chala Anna Hennadiivna - Ph.D. in Pedagogy, Associate Professor at the Department of Ukrainian Linguistics, Literature and Teaching Methods, Municipal Establishment «Kharkiv Humanitarian-Pedagogical Academy» of Kharkiv Regional Council; Rustaveli Ln., 7, Kharkiv, 61001, Ukraine.

Надійшла до редакції 15 вересня 2020 року

\section{CITATION}

ДСТУ 8302:2015: Крехно Т. І., Демченко Н. Д., Чала А. Г. Словникова стаття як метамовний когнітивно-комунікативний конструкт. Лінгвістичні дослідження: $з б$. наук. пр. Харк. нац. пед. ун-ту імені Г. С. Сковороди. Харків, 2020. Вип. 53. С. 176-191. DOI: https://doi.org/10.34142/23127546.2020.53.16

APA: Крехно, Т. І., Демченко, Н. Д., \& Чала, А. Г. (2020). Словникова стаття як метамовний когнітивно-комунікативний конструкт. Лінгвістичні дослідження, 53, 176-191. DOI: https://doi.org/10.34142/23127546.2020.53.16 